\title{
Marguerite Reads Giovanni: Gender and Narration in the Heptaméron and the
}

\author{
Decameron
}

\author{
ELIZABETH C. WRIGHT
}

$\mathrm{T}$ he theory of poetic "imitation" in sixteenth-century France stressed the assimilation of foreign words into French literature, using metaphors of natural processes. Joachim Du Bellay, for example, in his Deffence et Illustration de la Langue Françoyse (1549), called for French writers to "digest" Greek and Latin works, transforming them into their own "blood and nourishment," as Latin writers had done with Greek authors (I.vii); and Ronsard, borrowing from Horace, compared the process to that of a bee making honey from the nectar of various flowers. ${ }^{1}$

By contrast, Marguerite de Navarre, in the "Prologue" to her Heptaméron, while referring to a recent French translation of Boccaccio's Decameron as her source and inspiration, took pains to emphasize the difference between her work and his, to distinguish it from the previous one.

Boccaccio's tales are first described by Parlamente as the object of extravagant praise at the French court:

[J]e croy qu'il n'y a nulle de vous qui n'ait leu les cent Nouvelles de Bocace, nouvellement traduictes d'ytalien en françois, que le roy François, premier de son nom, monseigneur le Daulphin, madame la Daulphine, madame Marguerite, font tant de cas, que si Bocace, du lieu où il estoit, les eut peu oyr, il debvoit resusciter à la louange de telles personnes. ${ }^{2}$

However, when Parlamente evokes the French court's decision to imitate the tales, they establish their difference from Boccaccio's work through a series of negatives:

se delibererent d'en faire autant, sinon en une chose differente de Bocace: c'est de $n$ 'escripre nulle nouvelle qui ne soit veritable histoire. Et prosmirent les dictes dames et monseigneur le Daulphin avecq d'en faire chascun dix et 
d'assembler jusques à dix personnes qu'ilz pensoient plus dignes de racompter quelque chose, sauf ceulx qui avoient estudié et estoient gens de lettres; car monseigneur le Daulphin ne voulloit que leur art y fut meslé, et aussy de paour que la beaulté de la rethoricque feit tort en quelque partye à la verité de l'histoire (9; emphasis added).

Marguerite's protagonists adopt this project of the French court as their own, and the proposal to tell only "true" stories becomes a principle guiding their narrations. Boccaccio's Decameron is thus presented as both model and anti-model for the tales of the Heptaméron; a work to emulate, but one that by implication is false and deceptive.

The opposition between "truth" and "rhetoric" is of course a rhetorical strategy in itself, and is frequently repeated as a theme in the discourse of the work. In addition, Marguerite's alteration of the Decameron's narrative structures-occulting the first-level narrator and adding extensive debates following the stories-creates a tension between "objective" and "subjective" narration on a formal level. Some critics have emphasized Marguerite's spiritual or didactic purpose in these transformations ${ }^{3}$, while others have analyzed the complexity of her form as a mark of modern narrative. ${ }^{4}$ The role of gender in shaping this relationship, however, has not been fully explored in the critical literature, neither as it informed the cultural context in which the two writers worked, nor as they inscribed it in their narratives. ${ }^{5}$

In analyzing Marguerite's stance in relation to Boccaccio's tales, it is important to note that the European novella genre was practiced almost exclusively by male authors. Before Marguerite's tales, only one other work of this type was presented as authored by a woman, the Comptes amoureux attributed to "Jeanne Flore," published in Lyon before 1540, and Claude Longeon has presented evidence that this pseudonym may have covered the identity of a male author, Etienne Dolet. ${ }^{6}$ It is perhaps not accidental that Marguerite did not attempt to publish her own tales during her lifetime, nor that they were attributed to an anonymous male author in their first printed edition. ${ }^{7}$

Indeed, Vives' influential treatise on "The Instruction of a Christian Woman" specifically forbade women even to read "Boccaccio's tales and all like his". ${ }^{8}$ In his opinion, books on love written in the vernacular were fit only for "idle folk". ${ }^{9}$ Marguerite's sponsorship of a new French translation of the Decameron certainly went counter to this injunction, and in his prefatory epistle dedicating the work to her, Emilio Ferretti insisted on the high moral value of the work as well as its art, directly addressing the condemnation of it as unfit for "chaste and honest minds".10 
Since Ferretti's was in fact the prevailing humanist view of the work in Marguerite's time, her interest in the Decameron may have been supported by it. An additional prohibition, however, might have dissuaded Marguerite from daring to imitate Boccaccio's "art," for the study and practice of "rhetoric" was also forbidden to women by many male humanist educators. ${ }^{11}$ In this context, Marguerite's presentation of her work as the "truthful" narrations of a mixed-sex group of aristocrats, untrained in "rhetoric," appears to echo the gender prohibitions of her time.

Boccaccio's work, however, presented female narratorial voices at the second narrative level, and addressed the tales to a public of women, features also found in some of his Italian followers, in contrast to the French practitioners of this genre, whose narrators were often men addressing an all-male public.

The representation of women's voices in the Decameron text thus may have encouraged Marguerite to add her own, but when she adopted Boccaccio's text as a model, she also set up an impersonal first-level narrator, who rarely intervenes with any direct commentary. ${ }^{12}$ By contrast, the Decameron's first-level narrator is a male authorial persona, whose playful discourse on gender differentiation serves to motivate the storytelling and continues to inform his interventions throughout the work.

The narrator of Boccaccio's "Proemio" expresses his desire to reciprocate for the help offered him by male friends when he was suffering from a burning passion conceived for a lady of superior rank. In a sudden switch, however, he states that it is "ladies" ("donne") who are more in need of this sort of comfort than men, due to their weaker and more delicate nature, and the social restrictions imposed upon them. The stories will thus be his way of expressing compassion for these differences, and of bringing solace to the less fortunate sex. ${ }^{13}$

By now placing all "ladies who love" ("quelle che amano") in an inferior position to all men, and giving himself the power to provide "support and diversion" ("soccorso e rifugio") for them through his tales, the narrator reverses the gender configuration of his initial story, where his lady was in a superior position, and he was in need of comfort. Thus while he claims to be telling the stories in order to make up for "Fortune"'s lack of kindness to women, they are also a way for him to compensate for his own lack of fortune in love. Narration becomes a kind of surrogate for love-making between himself and his previously inaccessible lady; "Love," now that he is no longer imprisoned by it, has granted him "il potere attendere a' loro piaceri" (Proemio 13-15). ${ }^{14}$

In the "Introduction to the Fourth Day," the narrator/author continues his theme of narrating for the ladies, but here they are once again in a superior position to him and to all men. He uses a fable of a boy whose father tried to 
hide him from the temptations of women to prove that all males are irresistibly attracted to them, and he further claims that ladies have provided the source of inspiration for his poetry rather than the Muses (IV, Introduzione 12-36).

In the "Author's Conclusion," however, he returns once again to an attitude of condescension towards women, justifying imperfections in the style of his stories by the fact that he had to transcribe them as they were told by the lady narrators, and also by the need to address an audience of "semplice giovinette" who had not "sharpened their wits" ("gl'ingegni assottigliati") by studying in Athens or Bologna or Paris (Conclusione dell'Autore 16-21; Musa and Bondanella 687-88).

The narrative motivation for the tales of the Decameron is thus directly linked to gender differentiation. The male narrator justifies addressing his stories to "ladies" based on their difference from men. They need consolation from him since they are more fragile and more oppressed by society than men, yet they are also irresistibly attractive to him and inspire his work.

By contrast, in the Heptaméron's "Prologue," the first-level narrator does not identify itself by gender and has no story of its own to tell; the only direct interventions by this voice in the "Prologue" deal with narrative technique (1; $10)$. In addition, this narrator gives over to the second-level narrators the task not only of telling the stories but also of writing them down, for Parlamente suggests that they present them as a gift to the French court upon their return (10). Further, the initial motivation for the storytelling is not attributed to this narrator's desire, as in the Decameron, but rather to a project formulated by members of the French court, as described above.

While the first-person narrator does not then claim to be the initiator of the work, the "madame Marguerite" named as one of the court members who formulated the project most likely designates the author herself, perhaps constituting a residue from earlier manuscripts where a single female narrator recounted the tale (Fontanella 375-78). Since the erasure of a personal narrative voice coincided with the organization of the tales into a format echoing the Decameron's, Marguerite's move away from it reads both as a critique of Boccaccio's male authorial persona's playful ideology of gender differentiation, and as a strategy to circumvent the gender prohibitions of her time-against women's reading of Boccaccio's work and practicing the art of rhetoric. ${ }^{15}$

Marguerite further transforms the gender of the Decameron's narrative voice in her depiction of the second-level narrators, the storytellers. Where Boccaccio again plays with gender reversals on this narrative level, Mar- 
guerite once more subverts his emphasis on gender differentiation, this time by establishing equality between her male and female narrators.

In the "Introduction to the First Day," Boccaccio's authorial persona presents the second-level narrators through a tale set in the time of the 1348 Plague in Florence. He emphasizes that during this catastrophe there was a general abandonment of traditional customs, including those regulating differences in men's and women's behaviour, and the breakdown of gender differentiation is presented as a symptom of social disorder. Due to the scarcity of servants, for example, ladies who were ill allowed themselves to be tended by male servants (I, Introduzione 29), and women forgot their traditional role in mourning rites, instead engaging in witticisms and laughter in situations of bereavement (I, Introduzione 32-34). Further, when the narrator introduces the seven ladies who have gathered in the church of Santa Maria Novella, he gives them fictional names because the present "laws relating to pleasure" are somewhat "stricter" than at the time of the Plague ("essendo oggi alquanto ristrette le leggi al piacere"), and the ladies might be shamed in the future for having narrated and listened to the tales (I, Introduzione 50; Musa and Bondanella 12).

The narrator thus emphasizes that any transgressions in gender boundaries that occur in the story of the narrators is a temporary phenomenon, taking place within a general breakdown of social order, and different from both past and present moral codes. Indeed, the initial daring suggestion by Pampinea, the oldest of the group, that the seven ladies leave Florence with only their servants, is tempered by the counsel of Filomena and Elissa, who remind the group that they are "women" ("femine"), and thereby unable to act wisely without guidance from men (I, Introduzione 74-76). Nevertheless, the seven ladies outnumber the three young gentlemen they invite to join them, and Pampinea's leadership role is evident, for it is she who invites the men, and who suggests once they are in the countryside that they should bring order to their enterprise by choosing a leader for each day. She is unanimously elected as the first Queen, and it is she who proposes the activity of storytelling as a pleasant diversion for the hotter part of the afternoon (I, Introduzione 87, 94-102, 109-12).

These ladies of action might seem then to represent compensatory figures to the confined ladies depicted in the "Proemio," who form the fictional audience for the narrator. ${ }^{16}$ The emphasis on the plague setting, however, points up the loosening of gender roles depicted here as essentially a "carnivalesque" phenomenon without lasting consequences. Their liberated behavior is not a lesson to be learned nor a model to follow, ${ }^{17}$ but a symptom of social disintegration. 
Marguerite's "Prologue" also tells the story of a catastrophe that leads to the narrators' gathering together in a setting where they will tell stories, but the assembled group of ten contains an equal number of men and women whose behavior is not differentiated by gender. Having improved their health through their stay at a Pyrénées spa, they are dispersed by a flood just as they were planning to return home, and the adventures that lead to their eventual reunion in a monastery demonstrate that women and men show equal courage and strength in the face of adversity.

Oisille, the oldest female character, walks through difficult mountain paths in order to arrive at a monastery, and Nomerfide and Ennasuite are able to escape from a bear by running swiftly down the mountain. While the other two female characters, Parlamente and Longarine, are saved from an attack by bandits by their two gentlemen suitors, Dagoucin and Saffredent, the linking of their victory with their sex is contradicted by the fact that the ladies' husbands are also victims of the attack, one of them dying from it. In addition, the group of bandits includes both the host and hostess of the lodging, and the gentlemen do not hesitate to kill her along with her husband. The narrator thus seems to be going out of its way not to link either virtue or strength to sex in this scene. Indeed, the last two male characters to be introduced also have to be saved by others. Geburon, pursued by bandits, is rescued by the three previously introduced gentlemen, and Simontault, who narrowly escapes drowning while attempting to cross the swollen river, is saved by a shepherd and guided by a monk to the monastery where he rejoins the other (2-6).

Male and female characters in this preliminary story are thus portrayed as equal in courage, physical strength and moral virtue, and the reunion of the aristocratic protagonists is arranged so as to bring together equal numbers of each sex: five and five, in contrast to Boccaccio's seven female and three male storytellers. The story, rather than representing a scene of social disorder and gender reversals as did Boccaccio's Plague, echoes instead the Biblical tale of the flood, where one creature of each sex was saved to begin life anew. ${ }^{18}$

Further, in the discussions concerning how to pass the time during their stay in the monastery, one sex is not given preeminence over the other. Oisille is first consulted as to how the group might avoid "ennuy" during its stay, but after she states that reading from the Bible is the only remedy she has found for her troubles, it is one of the male characters, Hircan, who intervenes with the suggestion that the group listen to Oisille's readings in the morning but also find a more physical pastime for the afternoon. Although he notes that he is "parlant pour la part des hommes," he has included women in his declaration of the group's need for physical exercise (8), in a passage which 
both echoes and modifies the Decameron narrator's vision in the "Proemio" of the restrictions placed on women's activities. ${ }^{19}$

Oisille defers to Hircan and asks him to name his choice of activity. $\mathrm{He}$ alludes to the idea that making love to his wife Parlamente would be his first choice, to which she responds by saying that they should eliminate activities in which only two people can participate and instead choose one suitable for a group (8-9). When he directs her to guide them, she suggests they complete the work based on Boccaccio's one hundred tales previously begun by members of the French court. The rest of the group happily accept this plan, and Simontault begins the first story (9-10). Thus while Oisille is singled out from the others to lead the morning activity of Bible reading, the choice of storytelling is arrived at through a dialogue between both sexes, and the direction of the groups passes alternately from female to male characters. ${ }^{20}$

By her portrayal of genuine equality between men and women in the narrative of her storytellers, Marguerite thus radicalizes Boccaccio's loosening of gender roles and reversals of sexual hierarchy on the second narrative level. This utopian vision is tempered, however, by her representation of gender roles in the tales themselves, where the storytellers have sworn to "tell the truth." Here, where Boccaccio's stories again emphasize comic and temporary reversals of gender imbalance, Marguerite's depict with equal force both individuals' attempts to assert sexual equality and the social obstacles they encounter.

The Decameron tales emphasize individual acts of liberation, temporary reversals of inequality whether based on gender or rank, at the same time that the status quo of law and custom is reaffirmed. ${ }^{21}$ While many of the stories depict intelligent and resourceful female characters who successfully challenge the social restrictions imposed upon them, Radcliff-Umstead points out that males "retain an institutional dominance" in the work. ${ }^{22}$ Women triumph in specific situations through their wit and/or trickery, ${ }^{23}$ but they generally do not challenge the laws and customs themselves which determined women's subordination to their parents or husbands. As Marcel Janssens points out, "the underlying myth of most tales concerns plainly the subservient position of woman, who is bound to submit to Nature, custom and law, but who succeeds in eluding all sorts of restraints, provided she is beautiful, witty and tricky". 24

Even in the tale of Madonna Filippa (VI.7), for instance, which would seem to be an exception to the above generalizations in that she openly challenges the law, her success is attributed to her "ready and amusing reply" rather than to a principle of equality. ${ }^{25}$ 
Indeed, the scene is already set for Filippa's exoneration before the questioning begins. The statute she defies, which mandated death for any woman caught in the act of adultery by her husband, is already criticized as harsh and reprehensible ("non men biasimevole che aspro") by the storyteller (VI.7, 4). When Filippa's husband has her summoned to court under this decree, the narrator emphasizes the courage she manifests by her decision to appear and confess to the charges, risking death, despite the advice of many friends and relatives (9-10). Her beauty, breeding and courage also immediately gain her the sympathy of the podestà, who hopes not to be forced to condemn her to death (11).

While boldly acknowledging the truth of the charges, Filippa challenges the statute on two grounds. First, that while it applies only to women, no women consented or were even consulted about its passage; and second, that it unjustly restricts women, "le quali molto meglio che gli uomini potrebbero a molti sodisfare" (14).

She then has the podestà ask her husband if she has ever refused him gratification, to which he replies that "senza alcun dubbio la donna ad ogni sua richiesta gli aveva di sé ogni suo piacere conceduto" (16). Her next question to the official, justifying her affair as a way to avoid wasting what was "left over," provokes great mirth from the citizens of Prato gathered to hear the case: "io che doveva fare o debbo di quel che gli avanza? debbolo io gittare ai cani? non è egli molto meglio servirne un gentile uomo che più che sé m'ama, che lasciarlo perdere o guastare?" (17).

Following her witty remark, the crowd unanimously declares her both "right" and "well-spoken," and then proceeds to modify the statute to punish only women whose infidelity is venal:

udendo cosi piacevol riposta, subitamente, dopo molte risa, quasi ad una voce tutti gridarono la donna aver ragione e dir bene: e prima che di quivi si partissono, a ciø confortandogli il podestà, modificarono il crudele statuto e lasciarono che egli s'intendesse solamente per quelle donne le quali per denari a' lor mariti facesser fallo (18).

Her husband, embarrassed and ashamed ("confuso"), leaves the scene of judgment, and Madonna Filippa, having won her freedom, returns triumphantly ("gloriosa") to her house.

Thus Madonna Filippa successfully challenges the law, but she wins not so much by her argument about the need for women to take an equal part in making the law, as by her own personal merit, and her witticism demonstrating women's superiority to men in the area of sexual drive. The principle is again one of reversal of gender hierarchy rather than abolition of it. The 
modification of the statute also does not uphold the principle of equality between women and men, for it still applies only to women, and punishes only women for the crime of adultery.

Marguerite's tales also depict many female characters who defy the customary roles imposed on their gender, but while their eloquence is often admirable, their actions are generally thwarted by those in power. This only serves to emphasize, however, the arbitrary nature of gender definition, and the debate which follow the stories further to develop this point, by presenting opposing views on gender distinctions which are never resolved. Thus the Heptaméron tales depict the enforcement of gender roles by those in power, and the impossibility for women to successfully negotiate more just treatment for themselves, at the same time that they point out in a more radical and absolute manner than the Decameron's the arbitrariness of gender distinctions themselves.

The Fifteenth Tale, for example, can be compared and contrasted to that of Madonna Filippa, for its female protagonist pleads eloquently for her right to love a man other than her husband. The tale is designed to portray women as equal to men, for Longarine introduces it as one that will show that there are women "ayans aussi bon cueur, aussy bon esprit, et aussy plaines de finesses que les hommes" (116).

A rich young woman married to a gentleman at the Court of Francis I is completely ignored for three years by her husband, who spends all his time with a woman who is also the King's lover. The young woman begins to develop a friendship with a prince of the Court, but he is reprimanded by the King, and told to cease pursuing her, which he does. When her husband learns of this, he begins to notice his wife and attempts to get back in her good graces, but she is now determined to take her revenge, "desirant luy rendre partye des ennuictz qu'elle avoit euz pour estre de luy peu aymé” (119). She finds friendship with another gentleman, and her husband promises to kill her if he learns of her speaking to the man she loves either in public or private; when he discovers that she has asked her lover to come to her chamber at night, he summons her immediately to his room.

On this occasion she, like Madonna Filippa, gives an eloquent speech in her own defense, confessing that she has sought out this man and loves him (although her pleasure has been limited to talk and kisses). She condemns her husband's behavior while excusing her own, though her reasoning is moral, rather than an argument for women's sexual superiority as in Filippa's tale. She affirms her ultimate equal status with her husband, not in human law but before God: "Et combien que la loy des hommes donne grand deshonneur 
aux femmes qui ayment autres que leurs mariz, si est-ce que la loy de Dieu n'exempte poinct les mariz qui ayment autres que leurs femmes" (123).

Since her husband is this woman's only earthly judge, however, she is not vindicated, for he is "tant surpris d'estonnement" by her courage and eloquence that he can only reply by reiterating the double standard for men's and women's honor (124). Totally isolated at the Court, without any community support of the type Filippa enjoyed (the King remains loyal to her husband), this young woman continues to be persecuted by her husband in her attempts to find love.

Where Boccaccio's story of Filippa makes us laugh by showing how a superior woman can successfully flaunt an unjust law imposed on her by men, Marguerite's tale demonstrates that a woman can desire love and sexual fulfillment on an equal basis with a man and, despite her cleverness and beauty, still be thwarted in her attempts to break out of the submissive role assigned her. Madonna Filippa is able to resolve her situation by confronting the law and reversing the balance of power, but the only forum where it is suggested that the woman of the Fifteenth Tale will win the equality she desires is in God's judgment. The tale is much more troubling than funny, for it portrays a rigid enforcement of gender differences at the same time that it proves them to be completely arbitrary.

Further, the discussion which follows emphasizes the woman's transgression of her gender. Longarine, the narrator of the tale, seconded by Parlamente, condemns the woman's behavior as unworthy of "une femme de bien," who must remain loyal to her husband no matter how he treats her. Simontault then actually challenges the woman's gender characterization by saying that she had abandoned a woman's role by taking revenge on her husband rather than maintaining her honor: "celle dont le compte est faict a oblyé, pour ung temps, qu'elle estoit femme; car ung homme n'en eust sceu faire plus belle vengeance" (128).

This discussion of a different moral standard for men's and women's behavior is an elaboration of the husband's comment in the tale, and in the debates following the Twenty-First, Twenty-Sixth, and Forty-Third Tales, the narrators engage in similar discussions where the difference between men's and women's "honor" is defined in a like manner; i.e., that men's honor consists in seeking pleasure, while women must restrain their sensual nature and remain chaste. A remark similar to Simontault's is made by Parlamente in the discussion of the Forty-Third Tale:

[C]elles qui sont vaincues en plaisir ne se doibvent plus nommer femmes, mais hommes, desquelz la fureur et la concupiscence augmente leur honneur; 
car ung homme qui se venge de son ennemy et le tue pour ung desmentir en est estimé plus gentil compagnon; aussy est-il quant il en ayme une douzaine avecq sa femme. Mais l'honneur des femmes a autre fondement: c'est doulceur, patience et chasteté (301).

These statements also indicate that women's behavior often does not correspond to the standards enunciated by their code of honor, however, and this code is also characterized in the debate as a cover-up, or mask, for women's "true nature." Further on in the discussion following the Fifteenth Tale, Saffredent contradicts Simontault by saying that to be a woman does not consist in the trappings of honor but rather in the sexual desire hidden by women's dress, a point also made by Hircan after the Twenty-First and Twenty-Sixth Tales: "Toutesfois, dit Saffredent, si estes-vous toutes femmes, et quelques beaulx et honnestes accoustremens que vous portiez, qui vous chercheroit bien avant soubz la robbe vous trouveroit femmes" (128).

In this discussion, as in the others, these two opposing definitions of women are allowed to co-exist without resolution. On the one hand, they are said to lose their womanhood if they fail to adhere to the standards for women's "honor"; on the other hand, they are seen as essentially sensual in nature. Closure occurs only when one of the narrators demands that they go on to the next story to avoid spending all day in argument. Thus while the discussions which follow the tales in fact highlight the systems of gender differentiation posited by society, the clash of contrasting definitions of gender actually negates the absolutism of the viewpoints presented, and gender is revealed as an arbitrary social construction. ${ }^{26}$

The Fifteenth Tale is typical of the Heptaméron in its presentation of the conflict between women's behavior and the code of honor which demands chastity from them. Women are shown to have the same desires as men, but must obey a different standard which forbids them to act on these desires, and the debates following the tales further emphasize this point by presenting conflicting definitions of what it is to be a "woman." Women who realize their illicit sexual desires in the Heptaméron tales do so most often not by open challenge but by secrecy and silence, and are still condemned in the narrators' judgment (Tales $1,3,6,7,8,30,43,48$ ), while those who openly challenge the restrictions on their sexual freedom are either dishonored or punished when their actions become known, whether or not they have justification (Tales $21,36,40,53,60,61){ }^{27}$

In the Decameron, by contrast, this dilemma is generally resolved through comic reversals of gender roles, as in Filippa's story, and only exceptionally 
treated tragically, as in Ghismonda's story (IV.1) and other tales of the Fourth Day. Boccaccio's work thus shows compassion for women's plight, but generally cuts through their conflicts with an ease and freedom available only to men in his society.

The Heptaméron instead leaves the reader troubled by the conflicts experienced by women in Marguerite's society. While equality between the second-level male and female storytellers is established in the frame story, the erasure of a personalized authorial persona at the first level of narration, as well as the unresolved dilemmas posed in the tales and their commentary, serve to point up the difficulties women encountered in attempting to assert their desires.

The strategies Marguerite de Navarre used in rewriting the gender of Boccaccio's narrative voice point to the restrictions on women's speech in her society, and both her submission to and portrayal of these restrictions convey certain painful "truths" about women's situation which were glossed over by the "rhetorical beauty" of the Decameron. Her rewriting of the gender of narration and the narration of gender in the Decameron depicts a very modern viewpoint on equality between the sexes, challenging the notion of gender itself by portraying it as an arbitrary social construction, at the same time that it describes the thwarting of this potential equality in the social reality of her time. She both uses the Decameron as nourishment for her work and also "remains elsewhere," revising and subverting it to portray her own personal vision. ${ }^{28}$

\section{San Francisco State University}

\section{Notes}

1. Cited in Henri Weber, La création poétique au XVIe siècle en France, de Maurice Scève à Agrippa d'Aubigné, 2 vols. (Paris: Nizet, 1955), 1:123. For a full discussion of Renaissance imitatio, see Thomas M. Greene, The Light in Troy: Imitation and Discovery in Renaissance Poetry (New Haven: Yale University Press, 1982).

2. Marguerite de Navarre, L'Heptaméron, ed. Michel François (Paris: Garnier, 1967) 9. All subsequent references will be to this edition.

3. Luigi Monga, in "Misogyny or Feminism? A Topos in the Early Renaissance Novella;" Fifteenth Century Studies, 10 (1984) 121-33, concluded that marguerite "adds a spiritual stress" to Boccaccio's "healthy, but too naturalistic viewpoint" (130), and Donald Stone also pointed out Marguerite's greater emphasis on educational values, in From Tales to Truths: Essays on French Fiction in the Sixteenth Century, Analecta Romanica Heft 34 (Frankfurt: Vittorio Klostermann, 1973), 21-28. Yves Delègue, in "L'Heptaméron est-il un anti-Boccace?" Travaux de linguistique et de littérature de l'Université de Strasbourg, IV. 2 (1966) 23-37, while viewing Marguerite's work as "exempt de tout didactisme," found in it an expression of disquieting conflicts specifically opposed to Boccaccio's theme of consolation (37). 
4. Volker Kapp (Trier), in "Der Wandel einer literarischen Form: Boccaccios Decameron und Margucrite de Navarres Heptaméron, "Poetica, 14 (1982), 24-44, has viewed the greater complexity and openness of Marguerite's form as an adaptation to the more complex demands of her courtly environment and an historically later level of consciousness (43-44). Philippe de Lajarte, "Le Prologue de l'Heptaméron et le processus de production de l'oeuvre," in Lionello Sozzi, ed., La nouvelle française à la Renaissance (Genève: Slatkine, 1981) 397-423, and John D. Lyons, "The Heptaméron and the Foundation of Critical Narrative," Yale French Studies, 70 (1986), 150-63, have characterized Marguerite's break with Boccaccio as the beginning of modern, self-conscious "critical" narrative; and Colette H. Winn, "An Instance of Narrative Seduction: The Heptaméron of Marguerite de Navarre," Symposium, 39.3 (1985), 21 7-226, relates it to both sixteenth-century and modern narrative strategies.

5. Deborah N. Losse's article, "Authorial and Narrative Voice in the Heptaméron," Renaissance and Reformation/Renaissance et Réforme, 11.3 (1987), 223-42, treats the impact of gender on narrative voice in the novella genre, and its inscription on the various levels of Marguerite's work, but does not fully develop the contrast to the Decameron. Monga's article demonstrates the way in which Marguerite develops a woman's viewpoint more fully by alternating "misogynistic" and "feminist" statements in her narrations and discussions, but does not fully elaborate the comparison with the Decameron in terms of the various levels of narrative voice in the two works. Emile Telle's study, in L'Oeuvre de Marguerite d'Angoulême, Reine de Navarre, et la querelle des femmes (1937; Geneva: Slatkine Reprints, 1969), is limited by his insisting that Parlamente is Marguerite's spokesperson in the work, thus narrowing the "authorial voice" to this one character's viewpoint.

6. "Du Nouveau sur les Comptes amoureux de Madame Jeanne Flore," Bibliothèque d'humanisme et renaissance, 44.3 (1982), 605-13.

7. Histoire des Amans fortunez, ed. Pierre Boaistuau (Paris: G. Gilles, 1558). Boaistuau does not name the author of the tales, but refers to "him" with masculine pronouns ("Introduction", iii).

8. De institutione feminae Christianae, cited in Ruth Kelso, Doctrine for the Lady of the Renaissance (Urbana, IL: University of Illinois Press, 1956), 73. First published in Latin in 1523, Vives' treatise, dedicated to Queen Catherine of England, and written as a guide for the education of Princess Mary, appeared in French translation in 1542, 1543 and four times in 1545 (Kelso 421, \#864).

9. Cited by Gloria Kaufman, "Juan Luis Vives on the Education of Women," Signs, 3.4 (1978), 894; this article analyzes in more detail the ambivalence of Vives' "feminism."

10. Anthoine Le Maçon, trans., Le Decameron de Messire Jehan Bocace, Florentin (Paris: Roffet, 1545), iii v. This is the new translation invoked in the Heptaméron "Prologue" previously cited. Glyn P. Norton, in "The Emilio Ferretti letter: a critical preface for Marguerite de Navarre," Journal of Medieval and Renaissance Studies, 4.2 (1974), 287-300, has analyzed the importance of this epistle for the composition of Marguerite's "Prologue," but without reference to Vives' treatise. See also $n 14$ below.

11. Lionardo Bruni, for example, in De studis letteris (c. 1405), stated that "rhetoric in all its forms" lay "absolutely outside the province of woman," cited by Ann Rosalind Jones, "Surprising Fame: Renaissance Gender Ideologies and Women's Lyric," in The Poetics of Gender, ed. Nancy K. Miller (New York: Columbia University Press, 1986), 
75. The first part of the article (74-81) gives a full presentation of the proscriptions on women's rhetoric by humanist educators.

12. In certain manuscript versions of Marguerite's tales, considered to be an earlier stage of the work, a single female narrator recounts the stories, with no "Prologue," nor division into days, nor reference to Boccaccio as a model. For a history of the text, see Lucia Fontanella, “Un codice sconosciuto delle 'Nouvelles' de Margherita de Navarra: contributo allo studio della genesi della raccolta," 361-78 in Sozzi, and Marie-Paule Hazera-Rihaoui's unpublished thesis, "Les premiers contes de Marguerite de Navarre (édition commentée du manuscrit français 1513 de la Bibliothèque Nationale)," 2 vols., diss., Lyon II, 1989, which is a detailed study of the single-narrator version.

13. Giovanni Boccaccio, Decameron, ed. Vittore Branca (Firenze: Le Monnier, 1965) Proemio 1-12, and Giovanni Boccaccio, The Decameron, trans. Mark Musa and Peter E. Bondanella (New York: Norton, 1982), 1-2. All subsequent references will be to these editions, using division names and sentence numbers from Branca, and page numbers from Musa and Bondanella, as above. Although Marguerite refers to Le Maçon's French translation in the "Prologue" as the source for her imitation, she probably was familiar with the Italian version as well.

14. The role of the narrator/author as an intermediary for love is also figured before the "Proemio" in the book's subtitle, "PRENCIPE GALEOTTO," referring to Lancelot's friend who acted as intermediary for him with Guinevere, and specifically evoking a passage in Book V of Dante's Inferno where Francesca identifies "Galeotto" as the book and author responsible for the consummation of the love between herself and Paolo (Branca 1n1).

In commenting on this aspect of the work, recent twentieth-century critics have tended to refute Francesco de Sanctis' naturalistic thesis, that the stories are "real panders to pleasure and to love," in History of Italian Literature, 2 vols. (New York: Harcourt, 1931), 1: 336. They instead interpret both the narrator's addressing the work to "ladies in love" and the "Galeotto" subtitle as ironic stances on Boccaccio's part; for example, Giuseppe Mazzotta, "The Decameron: The Marginality of Literature," University of Toronto Quarterly, XLIl.1 (1972), 68-69; Robert Hollander, Boccaccio's Two Venuses (New York, Columbia University Press, 1977), ch. 4 esp. 106-07; and Janet Levarie Smarr, Boccaccio and Fiammetta: The Narrator as Lover (Urbana, University of Illinois Press, 1986), 202 esp. n78.

However, fifteenth- and sixteenth-century Decameron interpreters seemed to regard these aspects of the text in their more literal, scandalous sense, since they dismissed or eliminated them in order to arrive at their interpretation of Boccaccio as a Christian moralist. Emilio Ferretti, for example, in his dedication of Le Maçon's 1545 translation to Marguerite, did not mention that the book was addressed to an audience of women, and refuted the title of Galeotto at the same time that he defended the work as proper for "chaste and honest minds": "mi son forse piu maravigliato che doluto di quelli che o, hanno dato titolo di principe Galeotto a questo sanctissimo libro, o, l'hanno stimato indegno desser rappresentato a le caste, $\&$ honeste menti".(iii v).

In fact, both the subtitle and the "Proemio" were eliminated in the most commonly reproduced French version of the Decameron before Le Maçon's 1545 translation: Le Decameron de Messire Jehan Bocace Florentin, trans. Laurent de Premierfait (Paris: Vérard, 1485), reprinted eight times between 1485 and 1541. Le Maçon, however, 
despite the Ferretti letter, did accurately translate the subtitle and the entire "Proemio," as did some manuscripts of the Premierfait translation, such as BN mss. fr. 240 and 1122; the latter was in the library of Marguerite's grandfather Jean d'Orléans, comte d'Angoulême. Marguerite thus had access to both a faithful translation of these aspects of the work, and to their dismissal or elimination by the interpreters of her time.

15. Cautions about damage to a woman's honor through first-person narration of sexual incidents is also the theme of both the Fourth and Sixty-Second Tales of the Heptaméron, neither of which are found in the manuscript versions with a single female narrator.

16. This is Shirley S. Allen's point of view in "The Griselda Tale and the Portrayal of Women in the Decameron," Philological Quarterly, 56 (1977), 7.

17. Joy Hambuechen Potter, Five Frames for the Decameron: Communication and Social Systems in the Cornice (Princeton: Princeton University Press, 1982), 24.

18. Delègue (32 and $\mathrm{n} 35$ ), as well as Betty J. Davis, The Storytellers in Marguerite de Navarre's Heptaméron, French Forum Monographs 9 (Lexington, KY: French Forum, 1978) 192-93; Judith D. Suther, "Marguerite of Navarre's Quiet Victory over Misogyny," Explorations in Renaissance Culture 2 (1975) 45-54; and Claude-Gilbert Dubois, "Fonds mythique et jeu des sens dans le 'Prologue' de l'Heptaméron," Etudes seiziémistes offertes à V.-L Saulnier, ed. Robert Aulotte (Genève: Droz, 1980), 164n40, have pointed out the equality Marguerite establishes between male and female storytellers, but do not derive this from her depiction of their behavior in the narrative events which serve to bring them together. Both Paula Sommers, "Marguerite de Navarre's Heptaméron: The Case for the Cornice," French Review, 57.6 (1984), 787, and Dubois 156-60, discuss the "Prologue"'s relationship to the Genesis flood, but without relating this to the play of gender in its narrative.

19. This is pointed out by Delègue 31-32 and $n 35$.

20. Lajarte has shown how Oisille's theoretical preeminence as the leader of the morning Bible-reading activity is effectively subverted in the work by the substantially greater space and importance given to profane discourse-the storytelling and debates-where her words carry no more weight than those of the other narrators. I find his argument more convincing than Paula Sommers', in "Feminine Authority in the Heptaméron: A reading of Oysille," Modern Language Studies, 13.1 (1983), 52-59, who sees Oisille as an "authoritative presence" in the work.

21. See Thomas M. Greene "Forms of Accommodation in the Decameron," Italica, 45.3 (1968), 297-313; Janet Levarie Smarr, "Symmetry and Balance in the Decameron," Mediaevalia, 2 (1976), 159-87; and Marga Cottino-Jones, Order from Chaos: Social and Aesthetic Harmonies in Boccaccio's Decameron (Washington: University Press of America, 1982).

22. "Boccaccio's Idle Ladies," in The Roles and Images of Women in the Middle Ages and Renaissance, ed. Douglas Radcliff-Umstead, University of Pittsburgh Publications on the Middle Ages and Renaissance Studies at University of Pittsburgh, 1975), 76-79.

23. I.5; II.9; III.3,.9; VI.4; VII.1-9; IX.1-2; and see Radcliff-Umstead, 78-97.

24. "The internal reception of the stories within the Decameron," Boccaccio in Europe: Proceedings of the Boccaccio Conference, Louvain, December 1975, ed. Dr. Gilbert 
Tournoy, Symbolae A.4 (Leuven/Louvain: Presses universitaires de Louvain, 1977), 145.

25. The tale's summary states: "Madonna Filippa dal marito con un suo amante trovata, chiamata in giudicio, con una pronta e piacevol risposta sé libera et fa la statuto modificare."

26. Similar unresolved conflicting viewpoints exist in Marguerite's allegorical play, particularly in one of the last ones, "Comédie de Mont de Marsan" (1548), written not long before her death. Robert D. Cottrell's study, The Grammar of Silence: A Reading of Marguerite de Navarre's Poetry (Washington: Catholic University Press of America Press, 1986), emphasizes her attempts to "see through words" in order to perceive the ultimate divine "Silence" (311-12); the debates in the Heptaméron also show that human narrative codes can provide no absolute answer.

27. Colette H. Winn discusses this in "La Loi du non-parler dans l'Heptaméron de Marguerite de Navarre," (Kentucky) Romance Quarterly, 33.2 (1986), 157-68. By contrast, two articles in Chimères 15.2(1982), by Robert Bernard, "Feminist Rhetoric for the Renaissance Woman in Marguerite de Navarre's Heptaméron", 73-89 and Martha Perrigaud, "The Self-Made Cuckold: Marguerite de Navarre and Parole féminine", 55-71, emphasize the ways in which female protagonists assert their rights through rhetoric in the Heptaméron. While I agree that Marguerite has depicted female characters in the tales who forcefully and convincingly express their desire, my argument is that the tales and commentary show very clearly that this mastery of "rhetoric" by women only increases the social obstacles and ostracism they face.

28. The reference is to Luce lrigaray's description of women's "mimesis" of male-authored discourse in "Pouvoir du discours, subordination du féminin," Ce sexe qui n'en est pas un (Paris: Minuit, 1977), 74:

Jouer de la mimésis, c'est donc pour une femme, tenter de retrouver le lieu de son exploitation par le discours, sans s'y laisser simplement réduire. C'est se resoumettre ... à des "idées", notamment d'elle, élaborées dans/par une logique masculine, mais pour faire "apparaître", par un effet de répétition ludique, ce qui devait rester occulté: le recouvrement d'une possible opération du féminin dans le langage. ... elles ne se résorbent pas simplement dans cette fonction. Elles restent aussi ailleurs. ... 